\title{
Effect of Ni and Co as Trace Metals on Digestion Performance and Biogas Produced from The Fermentation of Palm Oil Mill Effluent
}

\author{
Irvan \\ Chemical Engineering Department, University of Sumatera Utara \\ Jl. Almamater Komplek USU Medan 20155 Indonesia
}

irvandusu.ac.id

\begin{abstract}
Macro and micro nutrients are important ingredients for successful anaerobic digestion. The presence or lack of nutrients can enhance or limit the functioning of the fermentation process. Micro-nutrients most often reported as stimulatory are trace metals such as nickel, cobalt, iron, and zinc. The purpose of this research is to study the effect of nickel and cobalt as trace metals on digestion performance and biogas produced from the fermentation of palm oil mill effluent (POME). Anaerobic digestion was performed in a two litres stirred tank reactor and operated at a thermophilic temperature $\left(55^{\circ} \mathrm{C}\right)$. As raw material, a real liquid waste (POME) from palm oil mill was used. Fresh POME was obtained from a fat pit of palm oil mill's waste water treatment facility belongs to one of the palm oil company in North Sumatera which has VS concentration of 26,300 mg/L and COD value of $42,000 \mathrm{mg} / \mathrm{L}$. To gain precise results, complete recording and reliable equipment of digester were employed. Supporting materials were also needed such as sodium bicarbonate, ammonium bicarbonate, and hydrochloric acid solution. Variables observed were included M-alkalinity, total solid (TS), volatile solid (VS), and biogas production. Hydraulic retention time (HRT) was maintained at 6 days. Experimental results concluded that the reduction of trace metals concentration did not affect the TS and VS concentration and M-alkalinity.
\end{abstract}

Keywords - anaerobic digestion; biogas; palm oil mill effluent trace metal; thermophilic

Submitted: September 4, 2012

Accepted: December 15, 2012

\section{INTRODUCTION}

Palm oil mill effluent (POME) is one of byproducts which come out from various units in palm oil mills such as, sterilization process, clarification process, hydro cyclone (clay bath), and washing unit. POME cannot be directly discharged into the environment because concentration of chemical oxygen demand (COD) is more than $50,000 \mathrm{mg} / \mathrm{L}$ (Ngan, 2000). It is necessary to treat this POME before being discharged into the environment. Moreover, the amount of organic matter content in POME is potentially to be processed into biogas through anaerobic digestion process.

Anaerobic digestion is the biological conversion of organic matter into methane $\left(\mathrm{CH}_{4}\right)$ and carbon dioxide $\left(\mathrm{CO}_{2}\right)$. In general, composition of biogas is 55-75\% volume of $\mathrm{CH}_{4}$ and $25-45 \%$ volume of $\mathrm{CO}_{2}$. The biogas can be upgraded to vehicle gas (96-97\% volume of methane) or used for production of heat. A part of the generated biogas can be used at the biogas plant itself in order to provide for the internal energy requirement and digested slurry which is formed can be used as fertilizer (Appels et. al., 2008).

Macro- and micro-nutrients are important ingredients in anaerobic digestion. The presence of nutrients can enhance the functioning of the fermentation process. Macronutrients needed in the system are commonly considered to be nitrogen and phosphorus while micro-nutrients most often reported as stimulatory include the trace metals nickel, cobalt, iron, and zinc (Speece, 1996). However, the trace metals; nickel, cobalt, and iron are not necessarily present in adequate amounts. Furthermore, these trace metals are not necessarily bioavailable.

The addition of trace metals (nickel, cobalt, and iron) in fermentation of municipal waste can enhance biogas production from 14 to $50 \%$, because it exhibited increased acetate and/or propionate utilization rates upon supplementation with either nickel, cobalt, iron, or all three metals (Zitomer et. al., 2008). Furthermore, the addition of trace metal $15 \mathrm{mg} / \mathrm{L} \mathrm{Ni}$ and $10 \mathrm{mg} / \mathrm{L} \mathrm{Co}$ in the fermentation of molasses can increase COD reduction efficiency from $44 \%$ to $58 \%$ and also enhance biogas production up to $14.8 \%$ L/day (Espinosa et. al., 1996).

The effect of cobalt and nickel on the corrinoid and F430 content and on the growth of Methanosarcina barkeri on methanol was studied by Jiang (2006). Cobalt and nickel limitation was achieved and competition between cobalt and nickel uptake was observed. Uptake efficiency of cobalt was high at low cobalt concentration and decreased when the cobalt concentration in the medium was increased. Corrinoid and F430 content correlated positively with the cell content of the corresponding metal, but incorporation in the corrinoid (Jiang, 2006).

Based on the previous researches mentioned above, therefore the purpose of this research is to study the effect of $\mathrm{Ni}$ and $\mathrm{Co}$ as trace metals upon digestion performance and biogas produced from the fermentation of palm oil mill effluent (POME).

\section{EXPERIMENT, MATERIALS AND METHODS}

\section{A. Experiment and materials}

Material used in this research was POME taken from a fat pit of palm oil mill's waste water treatment facility belongs to one of the palm oil company in North Sumatera. As supporting materials were $\mathrm{NaHCO}_{3}$, hydrochloric acid solution, metallic solution of trace metal; $\mathrm{FeCl}_{2}, \mathrm{NiCl} 6 \mathrm{H}_{2} \mathrm{O}$, and $\mathrm{CoCl}_{2} \cdot 6 \mathrm{H}_{2} \mathrm{O}$. The addition of $\mathrm{NaHCO}_{3}$ is to maintain $\mathrm{pH}$ at 6.8 to 7.2 and content of M-Alkalinity $\geq 3000 \mathrm{mg} / \mathrm{L}$. While 
the addition of $\mathrm{FeCl}_{2}$ is to minimize $\mathrm{H}_{2} \mathrm{~S}$ production, and the addition of $\mathrm{NiCl}_{1} 6 \mathrm{H}_{2} \mathrm{O}$ and $\mathrm{CoCl}_{2} \cdot 6 \mathrm{H}_{2} \mathrm{O}$ are required for anaerobic microbial metabolism.

\section{B. Methods}

The fermentation process took place in a 2-litre-capacity transparent jar digester (EYELA, Model MBF 300ME) which was provided with double walled water jacket to control the temperature, valves for sampling, conduit for discharge and feeding, turbine propeller, and alarm indicator bulb anticipating temperature disorder. A data logger (KEYENCE, Model NR-250) was connected to computer to enable automatic recording of temperature and $\mathrm{pH}$, provided by censoring equipments attached to digester (Irvan et. al., 2012). The $\mathrm{pH}$ was maintained in the range of $6.5-7.8$ and $\mathrm{M}$ alkalinity was maintained $\geq 3,000 \mathrm{mg} / \mathrm{L}$ with the addition 2.5 $\mathrm{g}$ of $\mathrm{NaHCO}_{3} / \mathrm{L}$ POME and addition of nickel $0.49 \mathrm{mg} / \mathrm{L}$ and cobalt $0.42 \mathrm{mg} / \mathrm{L}$ at the loading up process.

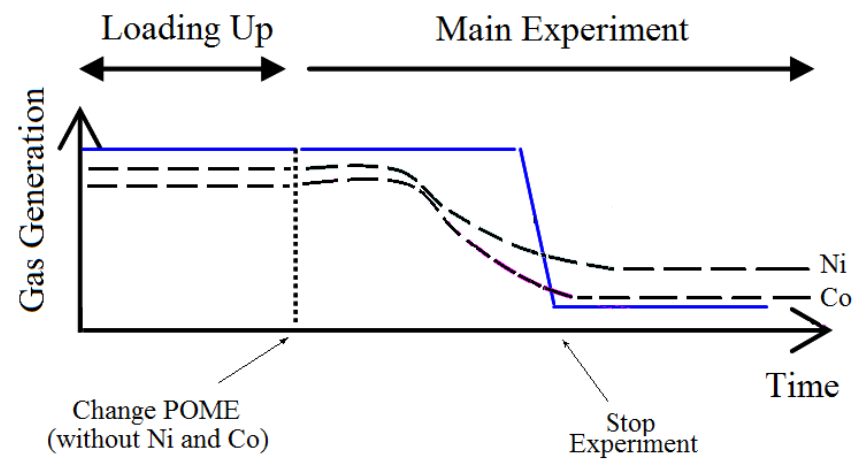

Figure 1. Experiment plan

Loading up was carried out based on several indications such as: the increased production of biogas which measured by using a gas meter, the decreased concentrations of total solids (TS) measured by weighing the samples which had been dried in an oven at $110{ }^{\circ} \mathrm{C}$ for 4 hours, and the decreased concentrations of volatile solids (VS) as measured by weighing the dried sample which had been heated in a furnace at a temperature of $700{ }^{\circ} \mathrm{C}$ for 2.5 hours. If the biogas production increased by $20 \%$, then the loading up was increased by $20 \%$ until it reached HRT 6 days. When HRT 6 days was reached, the addition of trace metal nickel and cobalt was stopped. The experiment was stopped when fermentor did not produce biogas anymore. It might be occurred when the fermentation process was lack of trace metal nickel and cobalt. Figure 1 shows experiment plan of this research. Concentration of $\mathrm{H}_{2} \mathrm{~S}$ and $\mathrm{CO}_{2}$ in the biogas were measured by using a suction gas injector (GASTEC, GV-100S type) and inspection tube (GASTEC, 25 1600 PPM).

\section{RESULTS AND DISCUSSIONS}

\section{A. Biogas production during the fermentation process}

The measurement of biogas produced during the fermentation process was performed by using a dry test gas meter (SINAGAWA, model DS). Figure 2 shows biogas generation during the fermentation process. During the loading up, the addition of nickel and cobalt at the beginning of the fermentation process were 0.49 and $0.42 \mathrm{mg} / \mathrm{L}$ respectively. After HRT 6 days was reached (on the $55^{\text {th }}$ day) and loading up was achieved (shown by the rise of biogas production which indicating microorganism in the fermentor has adapted well) the addition of nickel and cobalt were stopped. Stephenson and Lester has evaluated loading up process in the fermentation of livestock waste and obtained that loading up time was approximately 50 days by observing the increasing of biogas volume and the reduction COD value (Stephenson and Lester, 1986).

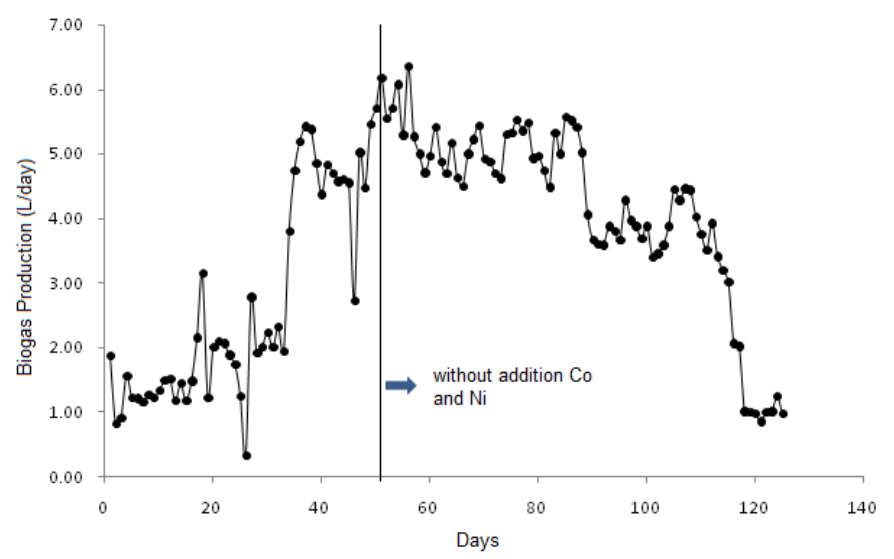

Figure 2. Biogas generation during the fermentation process

As shown in figure 2, gas generation at the beginning of fermentation was low. At this stage the microorganisms adapted to its environment. From the initial day to the $33^{\text {rd }}$ day, biogas was obtained at the range $0.82-2.78 \mathrm{~L}$ /day which indicating microorganism started to adapt. Biogas generation started to increase on the $34^{\text {th }}$ day and reached its higher volume $6.36 \mathrm{~L} / \mathrm{d}$ on the $56^{\text {th }}$ day. Indicating that microorganisms inside the fermentor, especially methanogens, have adapted very well, therefore it could produce biogas in large volume and high methane composition. (> 60\%). This is in accordance with start up process for fermentation of glucose performed by Alkarimiah et.al. They reported that methane composition during 40 days of initial experiment only reached $15 \%$, then increasing up to $36 \%$ after reaching the $45^{\text {th }}$ days which giving indication that microorganisms condition have been stable (Alkarimiah et.al., 2011).

After the addition of nickel and cobalt were stopped on the $52^{\text {nd }}$ day, the gas generation decreased gradually although until the $89^{\text {th }}$ day the gas volume relatively high, above 4.7 L/day. This high volume of biogas could be obtained because biogas producer microorganisms were still stable since environmental condition and nutrient (such as trace metals) were still sufficient for the needs in the activity of methanogenic bacteria. The presence of nickel, cobalt, and iron can enhance biogas production significantly (Raju et. al., 1991). On the $113^{\text {th }}$ day, biogas production kept on decreasing although no troubles were occurred to the equipment or controller of the fermentor.

Low concentration of nickel and cobalt in the fermentor became the main reason of low biogas production because the rest of trace metals in the fermentor were insufficient for methanogenic bacteria to work optimally. Obstruction of biogas formation caused accumulation of volatile fatty acid nd then disturbing fermentation process (Zitomer et. al., 2008). Until the $126^{\text {th }}$ day of the experiment, biogas production only achieved $1 \mathrm{~L} / \mathrm{day}$, no progress at all, then finally stopped on the $128^{\text {th }}$ day. This was due to trace metals presented in the 
fermentor has reached in very small concentration which was insufficient for the needs in the activity of methanogenic bacteria.

Based on volume of biogas obtained during the fermentation process it was observed that removal of nickel and cobalt as trace metals affecting on biogas production. When trace metals concentration inside the fermentor decreased then biogas production also decreased, this was due to the presence of trace metals can enhance acetate utilization rate to be converted to methane by methanogenic bacteria (Speece, 1996). Table 1 shows the trace metals composition in liquid fermentor after loading up and no addition of trace metals anymore.

Tabel 1. Trace metals concentration inside the fermentor and biogas production

\begin{tabular}{cccl}
\hline Days & $\begin{array}{c}\text { Biogas } \\
(\mathbf{L} / \mathbf{d a y})\end{array}$ & $\begin{array}{c}\text { Nickel } \\
(\mathbf{m g} / \mathbf{L})\end{array}$ & $\begin{array}{c}\text { Cobalt } \\
(\mathbf{m g} / \mathbf{L})\end{array}$ \\
\hline 52 & 5.85 & 0.53 & 0.45 \\
54 & 6.07 & 0.5 & 0.39 \\
100 & 3.88 & 0.18 & 0.08 \\
126 & 0.25 & 0.14 & 0.04 \\
\hline
\end{tabular}

On the $52^{\text {nd }}$ day, nickel and cobalt concentration were still 0.53 and $0.45 \mathrm{mg} / \mathrm{L}$ respectively. These concentration values were accumulation of trace metals in POME and added trace metals into the fermentor. On the $55^{\text {nd }}$ day, nickel and cobalt concentration started to decrease and day after day became lower. This indicated methanogenic bacteria grew well using nickel and cobalt which presented inside the fermentor for their metabolism. If methanogens growth reached to 4.8 and $30 \mathrm{~g} / \mathrm{L}$, then nickel and cobalt consumption will be high (Zhang et. al., 2003). Based on the values, on the $100^{\text {th }}$ day when trace metals concentration have reduced to $70-80 \%$, biogas still can be produced although the volume have decreased.

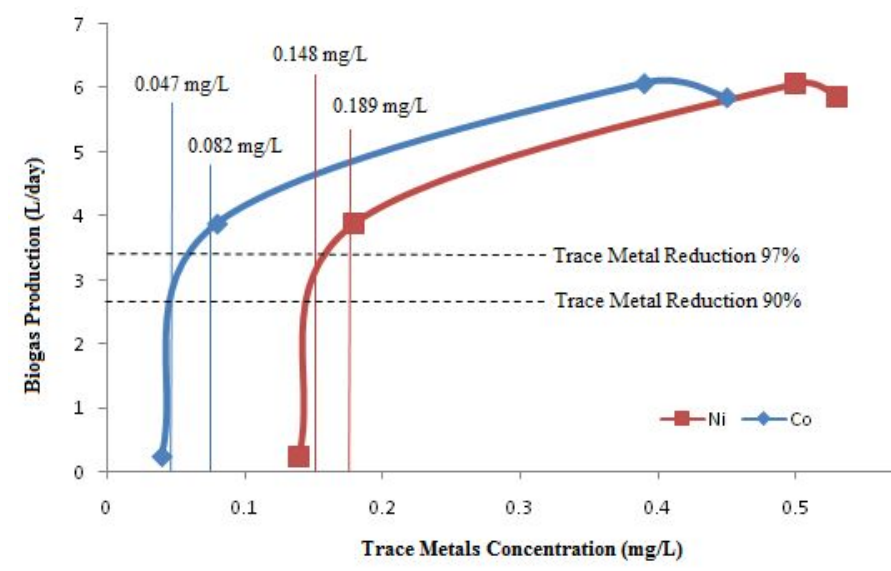

Figure 3. Trace metals concentration vs biogas production

Figure 3 shows trace metals concentration versus biogas production. As shown in figure 3 , the decline of biogas amount was along with the decline of trace metals concentration inside the fermentor. Then, experiments were performed by reducing trace metals up to $97 \%$ from the initial concentration. Although the concentration was reduced until
97\% but biogas in adequate amount was still obtained. Therefore, concentration of trace metals up to $90 \%$ or $97 \%$ are still possible to be reduced because biogas produced was still obtained in adequate amount.

\section{B. Effect of no addition of nickel and cobalt to total solid and volatile solid in fermentor}

Total solid (TS) is the amount of organic and inorganic matter contained in the waste water. While, volatile solid (VS) is the amount of organic matter converted into biogas in waste water (Schnurer and Jarvis, 2010). Biogas production is affected by amount of TS and VS in fermentor during the fermentation process. Figure 4 shows the amount of TS and VS of digested slurry in fermentor.

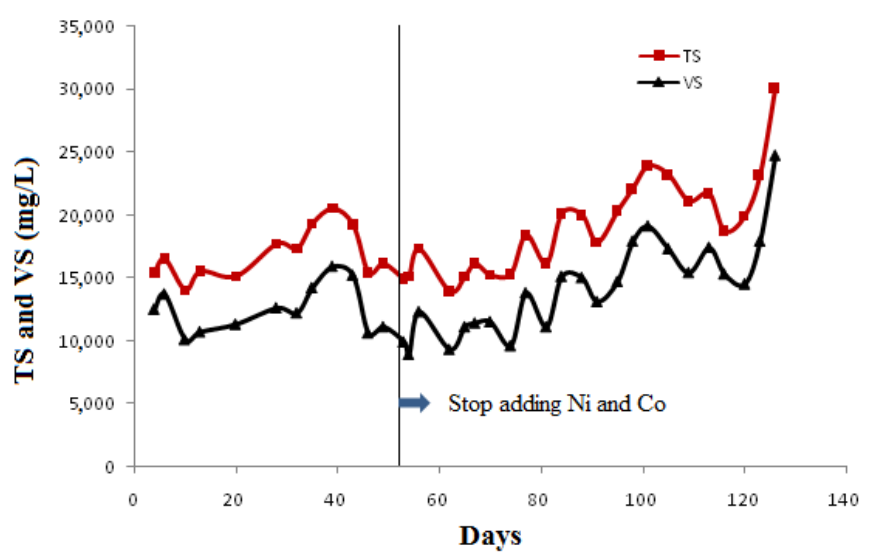

Figure 4. TS and VS inside the fermentor

As shown in figure 4 the tendency of TS reduction curve is similar to VS reduction curve. TS and VS concentrations inside the fermentor were high enough around 30,000 and $25,000 \mathrm{mg} / \mathrm{L}$. In the beginning of the experiment, it was shown that TS (range 15,000 to $20,000 \mathrm{mg} / \mathrm{L}$ ) and VS (range 12,000 to $16,000 \mathrm{mg} / \mathrm{L}$ ) concentration were relatively high, this was due to microorganism were still in adaptation phase. Therefore they were not able to degrade organic matters optimally. TS and VS concentration tend to decrease after the $46^{\text {th }}$ day, indicating that microorganism have adapted well, therefore enough VS to be degraded. After the addition of nickel and cobalt was stopped, the $52^{\text {nd }}$ day, VS and TS concentration were still below 15,000 and $20,000 \mathrm{mg} / \mathrm{L}$ respectively until the $97^{\text {th }}$ day. It might be occurred because the amount of nickel and cobalt in fermentor were still high enough since the accumulation of trace metal which came from fresh POME, previously. The presence of trace metals in anaerobic process can enhance methanogenesis up to $42 \%$ and also increase degradation rate of volatile solid and volatile fatty acid (Rao and Seenayya, 1994). On the $101^{\text {st }}$ day, VS concentration increased up to $19,100 \mathrm{mg} / \mathrm{L}$ and $23,900 \mathrm{mg} / \mathrm{L}$ for TS, although the decline of TS and VS concentration still occurred on the next day, however the values were still relatively high. Until the day of $126^{\text {th }}$, VS and TS concentration achieved to 24,700 and $30,100 \mathrm{mg} / \mathrm{L}$ respectively.

The increasing of TS and VS values were possibly caused by the low performance of degradation process of microorganism due to the lack of trace metals in the fermentor. Therefore, it can be concluded that trace metals can affect conversion of VS to biogas. The drop in TS and VS 
concentration at significant values indicated that methanogenesis process was working successfully, as a result optimum biogas production can be obtained.

If VS percentage in waste water is high enough then volume of biogas produced is also high. VS is amount of organic solid, higher VS concentration in waste water, higher biogas production if treated using anaerobic process (Igoni et.al., 2008). The drop in VS concentration of waste indicating that biodegradation process of organic matter occurred which increasing biogas production (Chiemchaisri et. al., 2007).

\section{Effect of no addition of nickel and cobalt to volatile solid decomposition}

The effect of no addition of nickel and cobalt to VS decomposition in the formation of biogas is shown in figure 5 . High percentage of VS decomposition indicated that biodegradation of organic matters occurred in the fermentor, and trace metals have an effect on the VS decomposition. Organic matter which degraded in anaerobic process will produce methane as final product, high decomposition of VS can be assumed as organic matter converted into biogas.

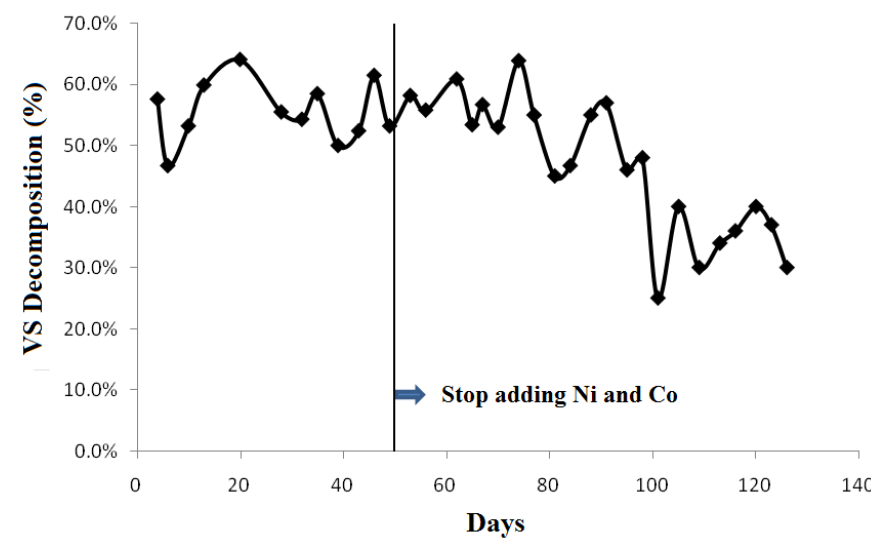

Figure 5. Volatile solid decomposition in the fermentor

As shown in figure 4, percentage of VS decomposition is still high, where an average VS decomposition percentage is above $50 \%$ at the initial experiment and even after the addition of nickel and cobalt is stopped. It might be because microorganisms consisted in the fermentor which degraded organic matters were in very good condition for growing since they have enough nutrition. However, on the $97^{\text {th }}$ day, VS decomposition percentage decreased up to $40 \%$, because the rest amount of trace metal in fermentor were insufficient for the needs in the activity of microorganisms. The presence of trace metals can influence the digestion or degradation of VS in anaerobic systems (Rao and Seenayya, 1994).

\section{CONCLUSIONS}

Results indicated that biogas generation reached its higher volume of $6.36 \mathrm{~L} / \mathrm{d}$ on the $56^{\text {th }}$ day, indicating that microorganisms inside the fermentor could produce biogas in large volume and high methane composition. Biogas production stopped on the $128^{\text {th }}$ day, due to trace metal concentrations were no longer sufficient for bacterial activity. Trace metals can affect conversion of VS to biogas, the drop in TS and VS concentration indicated that methanogenesis process was working well. VS decomposition percentage was above $50 \%$ initially, stable after no metals addition, and then dropped after that. Trace metals influenced the degradation of $\mathrm{VS}$ in fermentation of POME.

\section{ACKNOWLEDGEMENT}

This research was supported by Hibah Kompetitif Penelitian Unggulan Strategis Nasional No. 169/SP2H/PL/Dit.Litabmas /III/2012, date March 7 ${ }^{\text {th }}, 2012$ and Metawater Co., Ltd-Japan.

\section{REFERENCES}

[1] M.A. Ngan, "Management of Palm Oil Industrial Effluents", Advance in Oil Palm Research, vol. 2, Malaysian Palm Oil Board, Malaysia, 2000.

[2] L. Appels, J. Baeyans, J. Degrave, and R. Dewil, "Principles and Potential of The Anaerobic Digestion of Waste-Activated Sludge", Progress in Energy and Combustion Science, vol. 34, pp. 755-78, 2008.

[3] R.E. Speece, "Anaerobic Biotechnology for Industrial Wastewater", Archae Press. USA, Nashville, 1996.

[4] D.H. Zitomer, C.C. Johnson and R.E. Speece, "Metal Stimulation and Municipal Digester Thermophilic/Mesophilic Activity”, Journal of Environmental Engineering, vol. 134, no. 1, pp. 42-47, 2008.

[5] A. Espinosa, L. Rosas, K. Ilangovan, and A. Noyala, "Effect of Trace Metals on The Anaerobic Degradation of Volatile Fatty Acids in Molasses Stillage", Water Science and Technology, vol. 32, pp.121129, 1996.

[6] B. Jiang, "The Effect of Trace Elements on the Metabolism of Methanogenic Consortia", Wageningen University, Switzerland, 2006.

[7] Irvan, B. Trisakti, V. Wongistani, Y. Tomiuchi, "Methane Emission from Digestion of Palm Oil Mil Effluent (POME in a Thermophilic Anaerobic," International Journal of Science and Engineering, vol. 3 no. 1, pp. 32-35, 2012.

[8] T. Stephenson and J.N. Lester, "Evaluation of Startup and Operation of Four Anerobic Processes Treating a Synthetic Meat Waste", Biotech and Bioengineering, vol. 28 pp. 372-380, 1986.

[9] R. Alkarimiah, S.B. Mahat, A. Yuzir, M.F. Din, and Shreeshivadasan, "Operational Start-up Performance of an Innovative Anaerobic Stage Reactor (ASR) Using Synthetic Wastewater". Int. Conference on Environ. and Innovation, LACSIT Press, Singapore, 2011.

[10] N.R. Raju, S.S. Devi, and K. Nand, "Influence of Trace Elements on Biogas Production from Mango Processing Waste in $1.5 \mathrm{~m}^{3} \mathrm{KVIC}$ Digester", Biotechnology Letters, vol. 13, pp. 461-464, 1991.

[11] Y. Zhang, Z. Zhang, K. Suzuki, and T. Maekawa, "Uptake and Mass Balance of Trace Metals for Methane Producing Bacteria", Biomass and Bioenergy, vol. 25 pp. 427-433, 2003.

[12] A. Schnurer and A. Jarvis, "Microbiological Handbook for Biogas Plants", Swedish Waste Management, Sweden, 2010.

[13] P.R. Rao, and G. Seenayya, "Improvement of Methanogenesis from Cow Dug and Poultry Litter Waste Digesters by Addition of Iron". World Journal of Microbiol. and Biotech. vol. 10 pp. 211-214, 1994.

[14] A.H. Igoni, M.F.N. Abowei, M.J. Ayotammo, and C.L. Eze, 'Effect of Total Solids Concentration of Municipal Solid Waste on The Biogas Produced in an Anaerobic Continuous Digester", Agricultural Eng. Int: the CIGR E-Journal, vol. X, 2008.

[15] C. Chiemchaisri, W. Chiemchaisri, and S. Kumar, "Solid Waste Characteristics and Their Relationship to Gas Production in Tropical Landfill”, Environ. Monitoring Assess. vol. 135 pp. 41-48, 2007. 